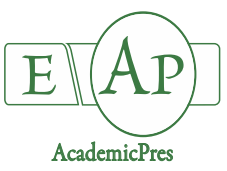

Kanatas P et al. (2020)

Notulae Botanicae Horti Agrobotanici Cluj-Napoca 48(2):871-881

DOI: $10.15835 /$ nbha48211887

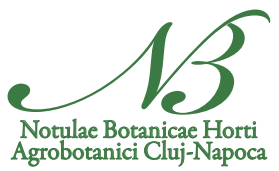

\title{
The effects of tillage on weed suppressive ability, leaf area, seed yield and protein content of Mucuna pruriens var. utilis
}

\author{
Panagiotis KANATAS ${ }^{1 *}$, Ioannis GAZOULIS ${ }^{2}$, Ilias TRAVLOS ${ }^{2}$, \\ Ioanna KAKABOUKI ${ }^{2}$, Sofia KIOUSSI ${ }^{2}$, Evgenia BABANIOTI ${ }^{2}$ \\ ${ }^{1}$ Agricultural Cooperative of Mesolonghi-Nafpaktia, 30200 Mesolonghi, Greece; pakanatas@gmail.com ("corresponding author) \\ ${ }^{2}$ Agricultural University of Athens, Department of Crop Science, 75 Iera Odos str., 11855,Greece; giangazoulis@gmail.com; \\ travlos@aua.gr;i.kakabouki@gmail.com;sofia.kioussi@gmail.com;stud115016@aua.gr
}

\begin{abstract}
In the field of the Agricultural University of Athens, the effects of tillage on weed suppressive ability, leaf area, seed yield and protein content of velvet bean (Mucuna pruriens) were evaluated under the climatic conditions of Greece. The experiment was carried out in a randomized complete block design with three replicates. The three experimental treatments were: control (untreated), one hoeing for weed seedlings' elimination at 7 days after sowing, and two hoeings for weed seedlings' elimination at 7 and 15 days after sowing. Findings revealed that one hoeing reduced annual weeds' density by $42 \%$ as compared to control treatment. Two hoeings resulted in a $47 \%$ lower density for annual species as compared to the untreated check. The density of perennial weeds recorded in the plots of one-hoeing treatment was $52 \%$ lower than the value recorded in the plots of control treatment. It was also shown that two hoeings can result in a $61 \%$ lower density regarding perennial species. Regarding velvet bean's vegetation growth, one hoeing increased velvet bean leaf area per plant by $26 \%$ whereas, in the plots of two-hoeings treatment, the value of leaf area per plant was by 22 $36 \%$ higher than the corresponding value recorded in untreated control plots. Two hoeings can increase velvet beans seed yield by $44 \%$ as well as seeds' protein content by $17 \%$. Further research is needed to optimize the use of velvet bean as a cover crop and seek for agronomic practices that might enhance its competitiveness against both annual and perennial weed species.
\end{abstract}

Keywords: cover crops; hoeing; leaf area; velvet bean; weed suppressive ability

\section{Introduction}

Mucuna pruriens var. utilis, widely known as velvet bean, is a vigorous annual climbing legume originally from southern China and eastern India, where it was at one time widely cultivated as a green vegetable crop (Duke, 1981). Among the various under-utilized wild legumes, velvet bean is widespread in tropical and subtropical regions of the world. It is cultivated in Asia, America, Africa, and the Pacific Islands, where its pods are used as a vegetable for human consumption, and its young leaves are used as animal fodder (Lampariello et al., 2012). It is considered a viable source of dietary proteins (Janardhanan et al., 2003; Pugalenthi et al., 2005) due to its high protein concentration $(\geq 23 \%)$ and digestibility, which are comparable to that of other pulses such 
as soybean, rice bean, and lima bean (Gurumoorthi et al., 2003). Velvet bean is also popular as a medicinal plant, which has been widely used in traditional Indian medicine (Sathiyanarayanan and Arulmozhi, 2007).

The induction of velvet bean in integrated or organic crop rotation systems can enhance the yield of the subsequent gramineous crops due to its increased nitrogen fixation and its positive effects on soil conditions (Sasamoto et al., 2013). Furthermore, velvet bean is known to have important agronomic traits such as low susceptibility to insect pests and increased ability to suppress weeds (Duke, 1981; Chikoye et al., 2004). The weed suppressive ability of velvet bean has been attributed to its rapid vegetation growth and canopy closure observed under favorable climatic conditions (Udensi et al., 1999; Ekeleme et al., 2003; Lawson et al., 2006). Moreover, velvet bean's allelopathic potential noxious weed species has been recognized (Ortiz-Ceballos et al., 2012; Travlos et al., 2018) and has been related to high concentrations of the amino acid levodopa or L-DOPA (L3, 4-dihydroxyphenylalanine) which is exuded not only from the leaves of velvet bean but also from the rooting system (Fujii, 2003).

Weed control is mainly dependent on herbicides whose increased use is associated with issues such as evolvement of weed resistance to herbicides, crop injury, soil and water pollution, toxicity patterns to nontarget organisms and concerns for human health (Li et al., 2003; Meksawat and Pornprom, 2010; Pot et al., 2014; Heap, 2014). Alternative weed management strategies such as using cover crops to suppress weeds, seedbed manipulations or tillage operations can be used for more effective weed management in integrated and organic farming systems (Reddy et al., 2003; Rasmussen, 2004; Hiltbrunner et al., 2007; Kanatas et al., 2020a). Cover crops suppress weeds either by smothering growth of established weeds or creating an environment that interferes with weed emergence and establishment (Teasdale, 1998). Cover crop species that emerge and grow rapidly the most effective competitors that deprive weeds of light, water, and nutrients ( $\mathrm{Lu}$ et al., 2000). There is evidence that velvet bean has great potential as a weed-suppressing cover crop. In the study of CaamalMaldonado et al. (2001) all legume cover crops reduced weed growth with velvet bean producing the largest weed biomass reduction and thus, the yield of corn (Zea mays) was increased at a significant point. Cover cropping with velvet bean has shown its great potential against both annual and perennial weed species. As a result, the beneficial effects on the grain yield of the subsequent crop are obvious and mainly related to less competition from weeds (Udensi et al., 1999; Chikoye and Ekeleme, 2001).

The main objectives of the present study were to evaluate the potential of velvet bean as a cover crop and to determine the effects of tillage on weed suppressive ability, growth, productivity, and quality of velvet bean under the climatic conditions of Greece.

\section{Materials and Methods}

Soil and climatic conditions

The soil of the experimental field is clay loam (CL) with a pH value of 7.29 (Table 1). The experiment was conducted in 2019 under typical climatic conditions for Greece (Table 2) and in an organic farming system.

Table 1. Soil conditions in the experimental field of the Agricultural University of Athens

\begin{tabular}{|c|c|}
\hline Parameter & Value \\
\hline $\mathrm{CaCO} 3$ & $15.99 \%$ \\
\hline Organic matter & $2.37 \%$ \\
\hline $\mathrm{NO}^{-}$ & $104.3 \mathrm{ppm}$ \\
\hline $\mathrm{P}\left(\right.$ Olsen $^{-}$ & $9.95 \mathrm{ppm}$ \\
\hline $\mathrm{Na}^{+}$ & $110 \mathrm{ppm}$ \\
\hline $\mathrm{pH}$ & 7.29 \\
\hline Soil type & Clay Loam $(\mathrm{CL})$ \\
\hline
\end{tabular}


Table 2. Mean maximum (Max $\mathrm{T}$ ), minimum temperature (Min $\mathrm{T}$ ) and rainfall values during the experimental period

\begin{tabular}{|c|c|c|c|}
\hline Month & $\begin{array}{c}\text { Max T } \\
\left({ }^{\circ} \mathrm{C}\right)\end{array}$ & $\begin{array}{c}\text { Min T } \\
\left({ }^{\circ} \mathrm{C}\right)\end{array}$ & $\begin{array}{c}\text { Rainfall } \\
(\mathrm{cm})\end{array}$ \\
\hline May & 24.2 & 15.8 & 0.07 \\
\hline June & 31.0 & 22.7 & 0.09 \\
\hline July & $32.6 \mathrm{a}$ & 23.8 & 0.03 \\
\hline August & $33.6 \mathrm{a}$ & 25.6 & 0.00 \\
\hline September & 29.0 & 21.0 & 0.16 \\
\hline
\end{tabular}

\section{Experimental treatments}

The experiment was carried out in a randomized complete block design with three replicates and three different treatments. The size of each plot was $2 \mathrm{~m} \times 3 \mathrm{~m}$. Seedbed preparation was carried out by ploughing at depth of $20 \mathrm{~cm}$ in May 3, 2019. Velvet bean sowing was carried out in May 6, 2019. The seeding rate of velvet bean was 75.000 seeds ha-1. The seeds were planted in ridges with a spacing of $60 \mathrm{~cm}$ between ridges and $30 \mathrm{~cm}$ between plant to plant. The three experimental treatments were: control (untreated), one-hoeing for weed seedlings' elimination at 7 days after sowing (DAS), and two-hoeing for weed seedlings' elimination at 7 and 15 DAS. Irrigations were made throughout the experimental period and especially during the initial crop growth stages.

\section{Measurements}

To evaluate velvet bean's weed-suppressing ability and the effects of the experimental treatments on weed flora, the densities of annual and perennial weeds were measured. Regarding the measurements of density, the number of plants per unit area was measured for annual and perennial weed species. After weed emergence, three $0.1 \mathrm{~m}^{2}$ quadrats were permanently marked in each plot. Quadrats were placed away from plot margins and in areas with uniform weed flora. Annual weeds were counted in each quadrat at 40 and 55 DAS. Perennial weeds were counted in each quadrat at 45 and 60 DAS. The number of plants counted per $0.1 \mathrm{~m}^{2}$ and recalculated to the number of plants per $\mathrm{m}^{2}$.

The average leaf area per plant $\left(\mathrm{m}^{2}\right)$ was also estimated in each plot for velvet bean. To evaluate this parameter, the product of the average length and the average width of leaves was estimated. Then the average leaf area was multiplied by the leaf number per plant to estimate leaf area per plant on each plot. The estimations were carried out at 35 and 70 days after sowing. Velvet bean was harvested in September 29 at 146 DAS. The number of pods per unit area, seeds per pod and weight of 1000 seeds were measured after harvest for the evaluation of velvet bean seed yield $\left(\mathrm{t} \mathrm{h}^{-1}\right)$. The protein content (\%) of the harvested seeds was also measured by using the classic Kjeldahl protein analysis.

\section{Statistical analysis}

Barlett's chi-square test for homogeneity of variance was tested and all data were subjected to Analysis of Variance (ANOVA) using STATGRAPHICS Centurion XVI. The effects of the experimental treatments on annual and perennial weeds' density, velvet bean LAI (Leaf Area Index) value, seed yield and protein content in the seeds were tested using ANOVA at a $=5 \%$ significance level. For the multiple comparisons between the means of the treatments, Fischer's LSD test was carried out at the 0.05 probability level. 


\section{Results}

\section{Effects of the experimental treatments on weed suppressive ability of velvet bean}

The dominant annual weeds emerged in the experimental area were Amaranthus retroflexus, Chenopodium album, Tribulus terrestris, Galium aparine and Portulaca oleracea. The effects of the experimental treatments on the density of annual weeds were not statistically significant regarding the measurement carried out at 40 DAS. However, it was noticed that the density of annual weed tended to be lower $(27-31 \%)$ in the plots where one or two-hoeing treatments were carried out in comparison to the values recorded in untreated plots. The differences became obvious in the results of the measurement carried out at 55 DAS. The ANOVA indicated that significant differences did exist and were further explained from the multiple comparisons between the means of the treatments. It was revealed that one hoeing reduced annual weeds' density by $42 \%$ as compared to control treatment. Two-hoeing resulted in a $47 \%$ lower density for annual species as compared to the untreated check. No significant differences were revealed between one-hoeing treatment and two-hoeing treatment (Table 3).

Table 3. The effects of experimental treatments on the density of annual weeds (plants $\mathrm{m}^{-2}$ ) at 40 and 55 days after sowing

\begin{tabular}{|c|c|c|}
\hline $\begin{array}{c}\text { Density of annual weeds } \\
\text { (plants } \text { ( }^{-2} \text { ) }\end{array}$ & $\begin{array}{c}40 \\
\text { DAS }\end{array}$ & DAS \\
\hline $\begin{array}{c}\text { Significance of P-Value for } \\
\text { "Treatment" }\end{array}$ & Ns & \\
\hline \multicolumn{2}{|c|}{} & LSD test for “Treatment" \\
\hline Untreated & $96.67 \mathrm{a}$ & $133.33 \mathrm{a}$ \\
\hline One hoeing & $70.00 \mathrm{a}$ & $76.67 \mathrm{~b}$ \\
\hline Two hoeings & $66.67 \mathrm{a}$ & $70.00 \mathrm{~b}$ \\
\hline
\end{tabular}

*Notes: DAS: Days after sowing. ${ }^{*}$ : Significant differences at the 0.05 probability level. Ns: Not significant differences; Different letters between the experimental treatments denote significant differences (LSD test, $\mathrm{p}<0.05$ ).

The dominant perennial weeds emerged in the experimental area were Sorghum halepense, Solanum elaeagnifolium, and Convolvulus arvensis. The effects of the different treatments on the density of perennial weeds were not proven statistically significant in the measurement carried out at 45 DAS. A significant difference was detected after analyzing data from the multiple comparisons between the means of the treatments, although. It was observed that the density of perennials was $59 \%$ lower in the plots where twohoeing operations were carried out as compared to the corresponding density observed in the untreated plots. In the plots of one-hoeing treatment perennials' density was $49 \%$ lower as compared to the density recorded in the plots of control treatment. Similar was the outcome of the measurement conducted at 60 days after sowing. The density of perennial weeds recorded in the plots of one-hoeing treatment was $52 \%$ lower than the value recorded in the plots of control treatment. It was also shown that two-hoeing can result in a $61 \%$ lower density regarding perennial species. In addition, neither in the first nor in the second measurement were significant differences observed between one-hoeing treatment and the two-hoeing treatment (Table 4). 
Table 4. The effects of experimental treatments on the density of perennial weeds (plants $\mathrm{m}^{-2}$ ) at 45 and 60 days after sowing

\begin{tabular}{|c|c|c|}
\hline $\begin{array}{c}\text { Density of perennial weeds } \\
\text { (plants } \text { - }^{-2} \text { ) }\end{array}$ & $\begin{array}{c}45 \\
\text { DAS }\end{array}$ & DAS \\
\hline $\begin{array}{c}\text { Significance of P-Value for } \\
\text { "Treatment" }\end{array}$ & Ns & \\
\hline \multicolumn{2}{|c|}{ LSD test for "Treatment" } \\
\hline Untreated & $163.33 \mathrm{a}$ & $190.00 \mathrm{a}$ \\
\hline One hoeing & $83.33 \mathrm{ab}$ & $90.00 \mathrm{~b}$ \\
\hline Two hoeings & $66.67 \mathrm{~b}$ & $73.33 \mathrm{~b}$ \\
\hline
\end{tabular}

*Notes: DAS: Days after sowing. ${ }^{*}$ : Significant differences at the 0.05 probability level. Ns: Not significant differences;

Different letters between the experimental treatments denote significant differences (LSD test, $\mathrm{p}<0.05$ ).

\section{Effects of the experimental treatments on leaf area per plant, seed yield and protein content of velvet bean}

Our results showed that the effects of the three different treatments on velvet bean's leaf area were proven statistically significant. This outcome was observed in the results of either the first or the second measurement. One-hoeing increased velvet bean leaf area by $26 \%$ as compared to control treatment in the measurement carried out at 35 DAS. A $15 \%$ increase was recorded from the results of the measurement carried out at 70 DAS, this difference was not proven significant although. In the plots of two-hoeing treatment, the value of the leaf area was by 36 and $22 \%$ higher than the corresponding value recorded in untreated control plots, as it was observed from the results of the first and the second measurement, respectively. At 70 DAS, it was shown that two-hoeing operations resulted in approximately $8 \%$ higher value for velvet bean as compared to one-hoeing operation. However, the difference between these two treatments was not significant as well as the difference observed at 35 DAS (Table 5).

Table 5. The effects of experimental treatments on velvet bean leaf area per plant $\left(\mathrm{m}^{2}\right)$ at 35 and 70 days after sowing

\begin{tabular}{|c|c|c|}
\hline Leaf area per plant & 35 & 70 \\
& DAS & $*$ \\
\hline $\begin{array}{c}\text { Significance of P-Value for } \\
\text { “Treatment" }\end{array}$ & $*$ & DAS \\
\hline \multicolumn{2}{|c|}{} & LSD test for “Treatment” \\
\hline Untreated & $1.16 \mathrm{~b}$ & $1.83 \mathrm{a}$ \\
\hline One hoeing & $1.58 \mathrm{a}$ & $2.16 \mathrm{ab}$ \\
\hline Two hoeings & $1.82 \mathrm{a}$ & $2.35 \mathrm{~b}$ \\
\hline
\end{tabular}

*Notes: DAS: Days after sowing. *: Significant differences at the 0.05 probability level. Different letters between the experimental treatments denote significant differences (LSD test, $\mathrm{p}<0.05$ ).

The effects of the experimental treatments on velvet bean seed yield were significant. In particular, it was observed that one-hoeing can increase velvet bean yield by $24 \%$ as compared to the case where no-hoeing operation is carried out. Although this increase is noticeable it was not statistically significant. However, in the plots of two-hoeing treatment, seed yield was up to $44 \%$ higher than the yield recorded in the plots of control treatment and this difference was proven statistically significant. It was also observed, that seed yield tended to be higher (26\%) in the plots of two-hoeing treatment than the value recorded in the plots of one-hoeing treatment (Table 7).

The adoption of the different treatments did also put a significant effect on the protein content in velvet bean seeds. It was noticed that one-hoeing treatment increased velvet bean's seed protein content by $11 \%$ as compared to the control treatment but this difference was not significant. In the plots of two-hoeing treatment, the seed's protein was $17 \%$ higher than the corresponding value recorded in the plots of control treatment and this difference was proven statistically significant. It was also observed, that velvet bean protein content tended 
to be higher $(6 \%)$ in the plots of two-hoeing treatment than in the plots of one-hoeing treatment but this difference was not significant (Table 8).

Table 7. The effects of experimental treatments on velvet bean seed yield $\left(t\right.$ ha $\left.{ }^{-1}\right)$ at 146 days after sowing (at harvest time)

\begin{tabular}{|c|c|}
\hline $\begin{array}{c}\text { Seed yield } \\
\left(\mathrm{t} \mathrm{ha}^{-1}\right)\end{array}$ & $\begin{array}{c}146 \\
\text { DAS }\end{array}$ \\
\hline \multicolumn{2}{|c|}{${ }^{*}$} \\
\hline LSD test for “Treatment" \\
\hline Untreated & $1.87 \mathrm{a}$ \\
\hline One hoeing & $2.48 \mathrm{ab}$ \\
\hline Two hoeings & $3.38 \mathrm{~b}$ \\
\hline
\end{tabular}

${ }^{*}$ Notes: DAS: Days after sowing. ${ }^{*}$ : Significant differences at the 0.05 probability level. Different letters between the experimental treatments denote significant differences (LSD test, $\mathrm{p}<0.05$ ).

Table 8. The effects of experimental treatments on protein content (\%) in the seeds of velvet bean at 146 DAS (Days after sowing) e.g at harvest time

\begin{tabular}{|c|c|}
\hline $\begin{array}{c}\text { Protein content } \\
(\%)\end{array}$ & 146 \\
DAS \\
\hline Significance of P-Value for “Treatment” & ${ }^{*}$ \\
\hline LSD test for “Treatment” \\
\hline Untreated & $22.67 \mathrm{a}$ \\
\hline One hoeing & $25.67 \mathrm{ab}$ \\
\hline Two hoeings & $27.33 \mathrm{~b}$ \\
\hline
\end{tabular}

${ }^{*}$ Notes: DAS: Days after sowing. ${ }^{*}$ : Significant differences at the 0.05 probability level. Different letters between the experimental treatments denote significant differences (LSD test, $\mathrm{p}<0.05$ ).

\section{Discussion}

\section{Effects of the experimental treatments on weed suppressive ability of velvet bean}

The results of the present study indicated that tillage operations such as hoeing can enhance weed suppressive ability of velvet bean. This outcome is in line with the findings of Udensi et al. (1999) who also reported that annual weeds' density was significantly reduced in tilled velvet bean plots as compared to the corresponding values recorded in untreated plots. The potential of velvet bean as a weed suppressive crop has been highlighted in a current study and the results are in agreement with the findings of other scientists (Lawson et al., 2006). According to Ekeleme et al. (2003), velvet bean can reach complete ground coverage at 16 weeks after sowing resulting in significant reductions in the density of annual weeds. There is evidence that tillage when combined with velvet bean cover cropping, can reduce annual weed infestation more effectively than cover cropping without any following hoe tillage operation (Chikoye et al., 2005). It is possible that velvet bean can take advantage of weed elimination as provided by one or two-hoeing and show great ability to compete with either annual or perennial weed species. This can be attributed to the rapid vegetative crop growth, a trait that is contributing to the wide promotion of velvet bean as a cover crop with noticeable competitive ability against weeds (Duke, 1981). Light requirements for seed germination and weed emergence have been reported for either annual weed species such as Sonchus asper and Echinochloa crus-galli or perennial weeds belonging to Solanum spp. (Milberg et al., 2000; Boyd and Van Acker, 2004; Zhou et al., 2005). Given that many weeds require light signals for seed germination and seedlings' emergence, their establishment in the field can be reduced due to shade conditions as provided from the rapid vegetative growth and ground coverage of velvet bean. Moreover, in the current study, irrigations were carried out during the whole experimental 
period and this might have enhanced velvet bean's competitive ability. It has been reported by Hartkamp et al. (2002) that sufficient water supply must be secured for the crop in order to obtain rapid canopy closure. The rapid growth of velvet bean under favorable environmental conditions can be attributed to quick seedling emergence due to the large size of its seeds (Kolawole and Kang, 1997).

The results of the current study revealed that tillage operations such as one or two-hoeing can enhance velvet bean's ability against perennial weeds. Although there is a concern if tillage operations exacerbate problems related to perennial weed infestation, it is established by Pekrun and Claupein (2006) that stubble tillage has the potential to significantly reduce their density. Such implements cut the rhizomes of perennial weeds fully and leave their roots and shoots in an upright position. Hoe tillage carried out in this experiment might have fragmented rhizomes of perennial species into portions that would not have adequate carbohydrates content for sprouting. There is evidence that cover cropping with velvet bean can contribute significantly in lowering rhizome biomass of perennial species, especially when combined with hoe tillage as compared to the case when no hoe tillage is carried out (Chikoye et al., 2005). Furthermore, velvet bean has the ability to suppress perennial weed species such as (Imperata cylindrica) even when no enhanced with weed control methods (Udensi et al., 1999). In the study of Chikoye et al. (2004) velvet bean was one of the most effective cover crops in reducing rhizome biomass of the same perennial species. The reason for its competitiveness might be related to other attributes except for rapid vegetative growth and ground coverage. From another aspect, velvet bean's ability to compete with perennial weeds might be attributed to the allelopathic potential of the crop. Its allelopathic effects on weeds has been attributed to L-DOPA which is exuded not only from leaves but also from the rooting system (Adler and Chase, 2007). Weed elimination through hoe tillage might have enabled velvet bean plants to develop a thick canopy with a remarkable density of leaves per unit area. Fresh velvet bean leaves contain L-DOPA as much as $1 \%$ of their weight. The irrigations carried out during the current experiment might have reduced weed infestation since L-DOPA also leaches out from leaves with rain drops or fog dew. Given that velvet bean produces 20 to 30 tons of fresh leaves and stems per hectare, a remarkable amount of L-DOPA may be transmitted to soil environment causing allelopathy effects on weed flora (Fujii, 2003). Furthermore, L-DOPA exudes from the rooting system whereas its concentration reaches $50 \mathrm{ppm}$ in the vicinity of roots, a value high enough to reduce the growth of neighboring plants (Fujii and Shibuya, 1991). However, the allelopathy effects of velvet bean should be further evaluated given that some cover crops have been reported to affect the establishment of the subsequent crops in a crop rotation system due to allelopathy (Haramoto and Gallandt, 2004).

Effects of the experimental treatments on leaf area per plant, seed yield and protein content of velvet bean It was observed that one or two-hoeing can increase the value of leaf area per plant for velvet bean. The purpose of this measurement was to provide as representative information as possible about the vegetative growth of the crop since the estimation of LAI (Leaf Area Index) value is a complicated issue regarding velvet bean crop (Dheebakaran and Jagannathan, 2009). In cereals, the average leaf area can be estimated as the product of the mean leaf size and a reduction coefficient that depends of the leaf shape (Owen, 1968; Ledent, 1976). Afterward, the average leaf area can be multiplied by the leaf density to calculate LAI value (Duchemin et al., 2006). However, the leaves of velvet bean are alternate, trifoliate, and are also characterized by other special morphological traits. Consequently, it is very difficult to make credible assessments regarding LAI value, and thus, it is more suitable to estimate leaf area per plant (Dheebakaran and Jagannathan, 2009). Velvet bean can be very effective in terms of weed management due to rapid growth and ground coverage. Such results have been shown in the study of Chikoye and Ekeleme (2001) who recorded up to 89\% ground cover for velvet bean at 10 weeks after sowing along with the long duration of shading in all their experimental locations. Regarding the results of the current experiment, the outcome of the second measurement carried out at 70 days after sowing was that two-hoeing treatment tended to increase leaf area per plant more than one-hoeing treatment. These results are in accordance with those of other scientists who noticed that weed elimination through hoeing can lead to increased ground coverage from velvet bean at 4 weeks after sowing (Udensi et al., 1999). It 
is well established that when enhanced by weed control practices, velvet bean tends to smother annual and perennial weeds by developing thick vegetation in quick time (Chikoye et al., 2005).

Regarding seed yield of velvet bean, it was increased either in the plots of one-hoeing treatment or in the plots of two-hoeing treatment. The difference was more obvious in the case where two-hoeing were carried out instead of no hoeing. Growing velvet bean plants in an open field as a sole crop and under favorable conditions of weed competition can enable the crop to reap more solar energy for photosynthetic activity. Less intra-specific competition for critical resources like water, nutrients, and photosynthetically active radiations results in higher values of important agronomic parameters such as vegetation growth and seed yield of velvet bean or medicinal crops (Karikalan et al., 2002; Sanwal et al., 2016). The results of the current study are in accordance with the findings of other scientists who have demonstrated that weed control by shallow tillage operations can increase seed yield in legume crops. For example, such observations have been made in peanut (Arachis hypogaea) or soybean (Glycine max) crop as well as in spring cereals (Johnson and Mullinix, 1995; Patil et al., 2013; Kanatas et al., 2020). However, the effects of weed management practices such as hoeing or shallow tillage operations on velvet bean's growth and yield should be further investigated since these attributes are also affected by genetic factors and show remarkable variability among various accessions of velvet bean (Chikoye and Ekeleme, 2001; Gurumoorthi et al., 2003; Pugalenthi and Vadivel, 2007; Dheebakaran and Jagannathan, 2009).

Regarding seed protein content, it was increased in the plots of one-hoeing or two-hoeing treatment. This outcome is in agreement with the findings of Peer et al. (2013) and Kanatas et al. (2020b) who also noticed that weed elimination throughout hand-weeding or tillage operations can be instrumental in increased seed protein content for legume crops. However, the effects of tillage on the seed protein content of velvet bean should be further investigated since it is a trait influenced by both environmental and genotypic factors that are difficult to separate (Fowler et al., 1990).

\section{Conclusions}

The results of the current study revealed that tillage can be a very effective strategy against weed infestation in velvet bean and result in greater weed suppression. It was noticeable that either one or two-hoeing can result in significantly reduced densities for both annual and perennial weed species. Two-hoeing enhance velvet bean's ability to develop a thick canopy due to rapid vegetation growth. Consequently, the effects of hoeing are also beneficial for seed yield and protein content of velvet bean. Further research is needed to optimize the use of velvet bean as a cover crop and seek for agronomic practices that might boost its competitiveness against weeds. The lack of new herbicide modes of action and the withdrawal of many of the available active ingredients due to the impact of European Union (EU) legislation indicates that alternative weed control strategies as the use of cover crops need to be evaluated for their efficacy against weed infestation and their effect on each crop's final yields.

\section{Authors' Contributions}

All authors listed have made a substantial, direct, and intellectual contribution to the work and approved it for publication. 


\section{Acknowledgements}

We are grateful to the editors and peer reviewers that gave of their time to ensure that the manuscript was strengthened via their insights.

\section{Conflict of Interests}

The authors declare that there are no conflicts of interest related to this article.

\section{References}

Adler MJ, Chase CA (2007). Comparison of the allelopathic potential of leguminous summer potential crops: cowpea, sunn hemp and velvet bean. HortScience 42(2):289-293. https://doi.org/10.21273/HORTSCI.42.2.289

Boyd N, Van Acker R (2004). Seed germination of common weed species as affected by oxygen concentration, light, and osmotic potential. Weed Science 52(4):589-596. https://doi.org/10.1614/WS-03-15R2

Caamal-Maldonado JA, Jiménez-Osornio JJ, Torres-Barragán A, Anaya AL (2001). The use of allelopathic legume cover and mulch species for weed control in cropping systems. Agronomy Journal 93(1):27-36. https://doi.org/10.2134/agronj2001.93127x

Chikoye D, Ekeleme F (2001). Growth characteristics of ten Mucuna accessions and their effects on the dry matter of Imperata cylindrica (L.) Rauesch. Biological Agriculture \& Horticulture 18(3):191-201. https://doi.org/10.1080/01448765.2001.9754883

Chikoye D, Schulz S, Ekeleme F (2004). Evaluation of integrated weed management practices for maize in the northern Guinea savanna of Nigeria. Crop Protection 23(10):895-900. https://doi.org/10.1016/j.cropro.2004.01.013

Chikoye D, Udensi UE, Ogunyemi S (2005). Integrated Management of cogongrass [Imperata cylindrica (L.) Rauesch.] in corn using tillage, glyphosate, row spacing, cultivar, and cover cropping. Agronomy Journal 97(4):1164-1171. https://doi.org/10.2134/agronj2003.0279

Dheebakaran G, Jagannathan R (2009). Estimation of Total Leaf Area by Nondestructive methods in Horse-eye Bean, Mucuna pruriens. Madras Agriculture Journal 96(1-6):113-115.

Duchemin B, Hadria R, Erraki S, Boulet G, Maisongrande P, Chehbouni A, ... Simonneaux V (2006). Monitoring wheat phenology and irrigation in Central Morocco: On the use of relationships between evapotranspiration, crops coefficients, leaf area index and remotely-sensed vegetation indices. Agricultural Water Management 79(1):1-27. https://doi.org/10.1016/j.agwat.2005.02.013

Duke JA (1981) Handbook of LEGUMES of World Economic Importance. Springer, Boston.

Ekeleme F, Akobundu IO, Fadayomi RO., Chikoye D, Abayomi YA (2003). Characterization of Legume Cover Crops for Weed Suppression in the Moist Savanna of Nigeria1. Weed Technology 17(1):1-13. https://doi.org/10.1614/0890-037x(2003)017[0001:colccf]2.0.co;2

Fowler DB, Brydon J, Darroch BA, Entz MH, Johnston AM (1990). Environment and genotype influence on grain protein concentration of wheat and rye. Agronomy Journal 82(4):655-664. https://doi.org/10.2134/agronj1990.00021962008200040002x

Fujii Y (2003). Allelopathy in the natural and agricultural ecosystems and isolation of potent allelochemicals from Velvet bean (Mucuna pruriens) and Hairy vetch (Vicia villosa). Biological Sciences in Space 17(1):6-13. bttps://doi.org/10.2187/bss.17.6

Fujii Y, Shibuya T (1991). A new bioassay for allelopathy with agar medium I. Assessment of allelopathy from litter leacheate by sandwich method. Weed Research Japan 36:150-151. https://ci.nii.ac.jp/naid/10011245355/

Gurumoorthi P, Kumar SS, Vadivel V, Janardhanan K (2003). Studies on agro-botanical characters of different accessions of velvet bean collected from western Ghats, south India. Tropical and subtropical Agroecosystems 2(3):105-115. https://www.redalyc.org/pdf/939/93920301.pdf 
Haramoto ER, Gallandt ER (2004). Brassica cover cropping for weed management: a review. Renewable agriculture and food systems 19(4):187-198. https://doi.org/10.1079/RAFS200490

Hartkamp AD, Hoogenboom G, White JW (2002). Adaptation of the CROPGRO growth model to velvet bean (Mucuna pruriens): I. Model development. Field Crops Research 78(1):27-40. https://doi.org/10.1016/s03784290(02)00090-4

Heap I (2014). Herbicide resistant weeds. In: Pimentel D, Peshin R (Eds). Integrated Pest Management. Springer, Dordrecht pp 281-301.

Hiltbrunner J, Liedgens M, Bloch L, Stamp P, Streit B. (2007). Legume cover crops as living mulches for winter wheat: components of biomass and the control of weeds. European Journal of Agronomy 26(1):21-29. https://doi.org/10.1016/j.eja.2006.08.002

Janardhanan K, Gurumoorthi P, Pugalenthi M (2003). Nutritional potential of five accessions of a South Indian tribal pulse, Mucuna pruriens var. utilis. Part I. The effect of processing methods on the contents of L-Dopa, phytic acid, and oligosaccharides. Journal of Tropical and Subtropical Agro-ecosystems 1(2-3):141-152. https://www.redalyc.org/pdf/939/93911288015.pdf

Johnson WC, Mullinix BG (1995). Weed management in peanut using stale seedbed techniques. Weed Science 43(2):293-297.https://doi.org/10.1017/S0043174500081200

Kanatas PJ, Travlos IS, Gazoulis J, Antonopoulos N, Tsekoura A, Tataridas A, Zannopoulos S (2020a). The combined effects of false seedbed technique, post-emergence chemical control and cultivar on weed management and yield of barley in Greece. Phytoparasitica 1-13. https://doi.org/10.1007/s12600-020-00783-x

Kanatas P, Travlos I, Papastylianou P, Gazoulis I, Kakabouki I, Tsekoura A (2020b). Yield, quality and weed control in soybean crop as affected by several cultural and weed management practices. Notulae Botanicae Horti Agrobotanici Cluj-Napoca 48(1):329-341. https://doi.org/10.15835/nbha48111823

Karikalan TV, Yassin MM, Duvya MP, Gopi D (2002) Effect of intercropping and nitrogen management on growth and yield of medicinal plants under kapok. Indian Journal of Agroforestry 4(2):88-93. https:// hdl.handle.net/20.500.12358/24382

Kolawole GO, Kang BT (1997). Effect of seed size and phosphorus fertilization on growth of selected legumes. Communications in Soil Science and Plant Analysis 28(13-14):1223-1235. https://doi.org/10.1080/00103629709369868

Lampariello LR, Cortelazzo A, Guerranti R, Sticozzi C, Valacchi G (2012). The magic velvet bean of Mucuna pruriens. Journal of Traditional and Complementary Medicine 2(4):331-339. https://doi.org/10.1016/S22254110(16)30119-5

Lawson IYD, Dzomeku IK, Asempa R, Benson S (2006). Weed control in maize Mucuna and Canavalia as intercrops in the Northern Guinea Savanna Zone of Ghana. Journal of Agronomy 5(4):621-625. http://www.docsdrive.com/pdfs/ansinet/ja/2006/621-625.pdf

Ledent JF (1976). Beam light interception by twisted leaf surfaces. Agricultural Meteorology 17(4):271-280. https://doi.org/10.1016/0002-1571(76)90031-5

Li Y, Sun Z, Zhuang X, Xu L, Chen S, Li M (2003). Research progress on microbial herbicides. Crop Protection 22(2):247-252. https://doi.org/10.1016/S0261-2194(02)00189-8

Lu YC, Watkins KB, Teasdale JR, Abdul-Baki AA (2000). Cover crops in sustainable food production. Food Reviews International 16(2):121-157. https://doi.org/10.1081/FRI-100100285

Meksawat S, Pornprom T (2010). Allelopathic effect of itchgrass (Rottboellia cochinchinensis) on seed germination and plant growth. Weed Biology and Management 10(1):16-24. https://doi.org/10.1111/j.1445-6664.2010.00362.x

Milberg P, Andersson L, Thompson K (2000). Large-seeded spices are less dependent on light for germination than smallseeded ones. Seed Science Research 10(1):99-104. https://doi.org/10.1017/S0960258500000118

Ortiz-Ceballos AI, Aguirre-Rivera JR, Osorio-Arce MM, Peña-Valdivia C (2012). Velvet bean (Mucuna pruriens var. utilis) a cover crop as bioherbicide to preserve the environmental services of soil. In: Alvarez-Fernández R (Ed). Herbicides-environmental impact studies and management approaches. University of Cambridge, Cambridge pp 167-184.

Owen PC (1968). A measuring scale for areas of cereal leaves. Experimental Agriculture 4(4):275-278. https://doi.org/10.1017/S0014479700009637 
Patil B, Reddy VC, Ramachandra PTV, Shankaralingappa BC, Devendra R, Kalyanamurthy KN (2013). Weed management in irrigated organic finger millet. Indian Journal of Weed Science 45(2):143-145. http://www.indianjournals.com/ijor.aspx?target=ijor:ijws\&volume $=45$ \&ssue $=2$ \&article $=017$

Peer FA, Hassan B, Lone BA, Qayoom S, Ahmad L, Khanday BA, ... Singh G (2013). Effect of weed control methods on yield and yield attributes of soybean. African Journal of Agricultural Research 8(48):6135-6141. https://doi.org/10.5897/AJAR11.1172

Pekrun C, Claupein W (2006). The implication of stubble tillage for weed population dynamics in organic farming. Weed Research 46(5):414-423. https://doi.org/10.1111/j.1365-3180.2006.00525.x

Pot V, Benoit P, Le Menn M, Eklo OM, Sveistrup T, Kvaerner J (2014). Metribuzin transport in undisturbed soil cores under controlled water potential conditions: experiments and modeling to evaluate the risk of leaching in a sandy loam soil profile. Pest Management Science 67(4):397-407. https://doi.org/10.1002/ps.2077

Pugalenthi M, Vadivel V (2007). Agrobiodiversity of eleven accessions of Mucuna pruriens (L.) DC. var. utilis (Wall. ex Wight) Baker ex Burck (velvet bean) collected from four districts of South India. Genetic resources and crop evolution 54(5):1117-1124. https://doi.org/10.1007/s10722-006-9003-x

Pugalenthi M, Vadivel V, Siddhuraju P (2005). Alternative food/feed perspectives of an under-utilized legume Mucuna pruriens var. utilis - a review. Plant Foods for Human Nutrition 60(4):201. https://doi.org/10.1007/s11130-0058620-4

Rasmussen IA (2004). The effect of sowing date, stale seedbed, row width and mechanical weed control on weeds and yields of organic winter wheat. Weed Research 44(1):12-20. https://doi.org/10.1046/j.1365-3180.2003.00367.x

Reddy KN, Zablotowicz RM, Locke MA, Koger CH (2003). Cover crop, tillage, and herbicide effects on weeds, soil properties, microbial populations, and soybean yield. Weed Science 51(6):987-994. https://doi.org/10.1614/P2002-169

Sanwal CS, Kumar R, Anwar R, Bhardwaj SD (2016). Performance of Mucuna prurience under chirpine (Pinus roxburghii) plantation of Mid Hills of Western Himalayas. Agricultural Research \& Technology: Open Access Journal 1(2):555560. https:// krishi.icar.gov.in/jspui/handle/123456789/23805

Sathiyanarayanan L, Arulmozhi S (2007). Mucuna pruriens Linn. A comprehensive review. Pharmacognosy Reviews 1(1):157-162. https://www.phcogrev.com/article/2007/1/1-17?qt-sidebar_tabs=1

Teasdale JR (1998). Cover crops, smother plants, and weed management. In: Hatfield JL, Buhler DD, Stewart BA (Eds). Integrated Weed and Soil Management MI: Ann Arbor Press, Chelsea pp 247-270.

Travlos I, Roussis I, Roditis C, Semini C, Rouvali L, Stasinopoulou P, ... Bilalis, D. (2018). Allelopathic potential of velvet bean against rigid ryegrass. Notulae Botanicae Horti Agrobotanici Cluj-Napoca 46(1):173-176. https:// doi.org/10.15835/nbha46110941

Udensi UE, Akobundu, IO, Ayeni AO, Chikoye D (1999). Management of cogongrass (Imperata cylindrica) with velvetbean (Mucuna pruriens var. utilis) and herbicides. Weed Technology 13(2):201-208. https://doi.org/10.1017/s0890037x00041610

Zhou J, Deckard EL, Ahrens WH (2005). Factors affecting germination of hairy nightshade (Solanum sarrachoides) seeds. Weed Science 53(1):41-45. https://doi.org/10.1614/WS-04-100RI
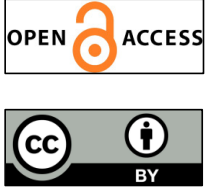

The journal offers free, immediate, and unrestricted access to peer-reviewed research and scholarly work. Users are allowed to read, download, copy, distribute, print, search, or link to the full texts of the articles, or use them for any other lawful purpose, without asking prior permission from the publisher or the author.

License - Articles published in Notulae Botanicae Horti Agrobotanici Cluj-Napoca are Open-Access, distributed under the terms and conditions of the Creative Commons Attribution (CC BY 4.0) License. (C) Articles by the authors; UASVM, Cluj-Napoca, Romania. The journal allows the author(s) to hold the copyright/to retain publishing rights without restriction. 